\title{
Antimicrobial effects of grape pulp, Bakhtiari savory, and lemon extracts on Listeria monocytogenes isolated from meat
}

\author{
Ehsan Ghasemi, Gholamreza Banisharif and Iman Alavi* \\ MSc Microbiology, College of Basic Science, Shahrekord Branch, Islamic Azad University, Shahrekord, Iran
}

\begin{abstract}
Listeria monocytogenes is a coccobacilli, gram-positive, non-spore forming bacteria. The distribution of these bacteria in nature is high, which is a human and animal pathogen and has different complications. The main transmission way for human infection is through the consumption of contaminated foods. This study is aimed to investigate the antimicrobial effects of Bakhtiari savory, grape pulp and lemon extracts against Listeria monocytogenes. The pulp extract of a kind of lemon and the aalcoholic extract of grape seed were extracted and the concentrations of 16 to $1000 \mathrm{mg} / \mathrm{ml}$ were prepared. The minced meat was infected with Listeria monocytogenes, and then the prepared concentrations of the extracts were injected into the meats carrying the bacteria. After 3, 7 and 10 days, a microbial culture was done from the meats and the colonies were counted. The study showed that the Bakhtiari savory extract and then the grape pulp has the greatest inhibitory effect both in vitro and in food. It was also shown that the Bakhtiari Savory could be effective as a preservative to increase meat durability and to prevent the growth of pathogens such as Listeria monocytogenes. According to the inhibitory effect of Bakhtiari Savory extract and the grape pulp on Listeria monocytogenes, the substances may be used for the treatment of diseases caused by these bacteria.
\end{abstract}

KEY WORDS: LISTERIA MONOCYTOGENES, MEAT, BAKHTIARI SAVORY, GRAPE PULP, LEMON

\section{ARTICLE INFORMATION:}

*Corresponding Author: Imanalavi66@gmail.com

Received $12^{\text {th }}$ March, 2017

Accepted after revision $31^{\text {st }}$ May, 2017

BBRC Print ISSN: 0974-6455

Online ISSN: 2321-4007 CODEN: USA BBRCBA

$\therefore$ Thomson Reuters ISI ESC and Crossref Indexed Journal

NAAS Journal Score 2017: 4.31 Cosmos IF : 4.006

- A Society of Science and Nature Publication, 2017. All rights reserved.

Online Contents Available at: http//www.bbrc.in/ 


\section{INTRODUCTION}

Listeria monocytogenes (L. monocytogenes) is a grampositive, non-acid-fast and short rod shaped, opportunistic intracellular, Gram-positive, facultative anaerobic, nonspore-forming bacterium of the genus Listeria, which is widely spread in the environment, and can cause severe diseases including meningoencephalitis, septicemia, mastitis and abortion in humans and animals, primarily affecting pregnant, new-born, and immunocompromised individuals (Dehkordi et al. 2013, Reddy and Lawrence 2014).

According to previous epidemiological investigations, various types of foods and especially those with animal origins are the main reservoirs for virulent strains of L. monocytogenes (Dehkordi et al. 2013, Di Pinto et al. 2010, Gray et al. 2004, Tompkin 2002). The high ability of bacterium to resistance against environmental conditions such as temperature, $\mathrm{pH}$, salt concentration and also dryness is the main reason for considerable role of the L. monocytogenes as an emerging food-borne pathogen (Mataragas et al. 2006, Zhang et al. 2012). Meat is raised as one of the most important reservoirs of the L. monocytogenes (Goh et al. 2012, Indrawattana et al. 2011, Siriken et al. 2013). Meat of animals prepares favorable conditions including optimum levels of nutritional materials, temperature, activated water (AW), $\mathrm{pH}$ and salt for persistence of L. monocytogenes (Mataragas et al. 2006, Zhang et al. 2012).

Antibiotic therapy is the most effective way to treatment the cases of food-borne listeriosis but high presence of antibiotic resistant strains of this bacterium cause hardness and prologues in treatment period and usually occur severe economic losses (Camargo et al. 2015, Dehkordi et al. 2013, Granier et al. 2011, Morvan et al. 2010). In keeping with this, an epidemiological research revealed that the $L$. monocytogenes strains of animal origins had the ranges of 10-80 percent resistance against commonly used antibiotics (Dehkordi et al. 2013). High prevalence of antibiotic resistance and increasing in the consumers' concerns regarding food security and consuming foods without any chemical preservative, led the food industries to use from the traditional plant extracts to reduce the microbial load of various types of foods (Kang et al. 2011). Now a days, application of medicinal plants and especially grape pulp, savory, and lemon due to their high antimicrobial effects and also complete contents of flavonols, antioxidants, phenolic acids, catkins, proantocianidine, anthocyanins, catkins, folic acids and other phenolic components have been increased in the food industries (Mahboubi and Kazempour 2011, Oliveira et al. 2013). However, using from medicinal planst in food industries requires more extensive research.
The aim of this study was to evaluate the antimicrobial effect of grape pulp, Bakhtiari savory, and lemon extracts on L. monocytogenes isolated from Iranian meat samples.

\section{MATERIALS AND METHODS}

\section{SAMPLES COLLECTION}

Grape sample was prepared from Shiraz native RISH BABA as well as the pulp extract dewatered from a kind of lemon, an extracted savory was also selected for the study. To dry the samples in a large volume, followed by the dewatering and the pulp separation, the grape cores were kept for a week at 25 to $30^{\circ} \mathrm{C}$ in the shade with proper ventilation.

\section{ESSENCE EXTRACTION AND PREPARATION}

The dried grape cores were kept in cool, dry place until the time of experiments. $100 \mathrm{gr}$ core was weighed in order to take the essence and extracting (Mahboubi and Kazempour 2011). In order to prepare the extracts, 96\% ethanol was used. For this purpose, the extraction was performed from 100 grams of vegetable using ethanol solvent, followed by concentrating the samples and alcohol separation using Rubia tinctorum in a vacuum (Siriken et al. 2013). To investigate the effective dose which has antibacterial properties, different concentrations were made from the extracts and selected doses were applied according to the sources.

To provide the desired concentrations, 0.01 gram of the extract was weighted and poured into the test tube, then 96\% Ethanol was added to the final volume of 10 $\mathrm{ml}$, followed by mixing thoroughly, the solution is called the Mother solution. Then the concentrations of 1000 , 500, 250, 125, 62, 31 and $16 \mathrm{mg} / \mathrm{ml}$ were prepared.

\section{STUDY THE ANTIMICROBIAL EFFECTS}

To investigate the antimicrobial effects of desired extracts, Hinton agar plates were used. To inoculate the bacteria, $100 \mu \mathrm{l}$ of bacteria suspension was poured on already prepared solid medium. Then, the liquid was spread over the medium surface using a sterile cotton swab or a sterile Pasteur L-shaped pipette. It was done identically for all the plates. Then, plate disks impregnated with the extracts were placed on the plates using sterile forceps, in the following, the antimicrobial properties were evaluated after 24 hours. To evaluate the antimicrobial properties of extracts and to determine the Minimum Bacterial Concentration $(\mathrm{MBC})$ and Minimum Inhibitory Concentration (MIC) of each extract, the concentrations of MBC and MIC were used for inoculating on food sample (meat). For 


\begin{tabular}{|c|c|c|c|c|}
\hline \multirow{2}{*}{ Extract } & \multirow{2}{*}{$\begin{array}{l}\text { Inoculated } \\
\text { bacteria }\end{array}$} & \multicolumn{3}{|c|}{$\begin{array}{l}\text { Bacterial counts in days after } \\
\text { inoculation }\end{array}$} \\
\hline & & 3rd & 7th & 10th \\
\hline \multirow{2}{*}{ Grape pulp } & 103 & $102 \times 2.2$ & $102 \times 9.5$ & $102 \times 8.8$ \\
\hline & 106 & $104 \times 1.4$ & $104 \times 6.6$ & $104 \times 8.6$ \\
\hline \multirow{2}{*}{ Savory } & 103 & $101 \times 8.3$ & $101 \times 4.5$ & $102 \times 2.5$ \\
\hline & 106 & $103 \times 3.6$ & $103 \times 8.5$ & $103 \times 3.4$ \\
\hline \multirow{2}{*}{ Lemon } & 103 & $102 \times 9.7$ & $102 \times 1.9$ & $103 \times 8.1$ \\
\hline & 106 & $104 \times 2.9$ & $105 \times 3.2$ & $105 \times 1.4$ \\
\hline
\end{tabular}

this purpose, beef minced meat with about 15\% fat was selected and minced with a meat mincer which the cutting blade, spiral parts and etc, were washed well and disinfected with 96\% alcohol and dried. The desired meat was packed in $10 \mathrm{~g}$ plastic bags and was sterilized in the presence of UV radiation for 3 hours. In the following, the meats were inoculated with $10^{3}$ and $10^{6}$ concentrations of L. monocytogenes in the both groups, and then the prepared concentrations of the extracts were injected into the meats carrying the bacteria. After 3, 7 and 10 days, $1 \mathrm{~g}$ of the desired meat was put into test tubes containing sterile distilled water and the desired concentrations were given to the medium, then the bacteria grown were counted after 24 hours.

\section{STATISTICAL ANALYSIS}

To analyze the data, the one-way analysis of variance was used, as well as Duncan's and Tukey's mean comparisons with 5\% probability level using SPSS statistical software (Ver. 20).

\section{RESULTS}

In the present study, the antibacterial effect of Bakhtiari savory, grape pulp and lemon pulp on L. monocytogenes was examined in vitro and in the minced meat.
The results of 5- 10, 6- 10 and 7- 10 dilutions during 3, 7 and 10 days following the counting of bacteria suggested the best inhibitory effect in the Bakhtiar savory, grape pulp and lemon extracts, respectively.

Also, Bakhtiari savory, grape pulp and the lemon extracts were prepared and the effect of MBC and MIC were evaluated. The results showed that the Bakhtiari Savory have the greatest inhibitory effect in vitro compared to the Grape pulp and lemon, respectively.

\section{DISCUSSION}

In general, the amount and the distribution of L. monocytogenes in nature and environment is very high. These bacteria can be found everywhere, from human and animal feces to the soil, water and the variety of foods such as raw meat, fruits, milk and their products (19 of 30). Therefore, human beings, as a member of nature, can easily be infected with the bacteria, certainly by exposing one of the above mentioned items and having special conditions (8 and 30). The main transmission way for human infection is through the consumption of contaminated foods. The use of chemical preservatives to increase food durability and to prevent the growth of pathogens has resulted in the increase of chronic and incurable diseases. Therefore, the consumers mainly purchase and prepare foods without

\begin{tabular}{|c|c|c|c|c|c|c|c|}
\hline Sampl & 1000 & 500 & 250 & 125 & 62.5 & 31 & 15 \\
\hline Grape pulp & $\begin{array}{l}16-18-18 \\
\text { MBC }\end{array}$ & $\begin{array}{l}\text { 17- } 17-17 \\
\mathrm{MBC}\end{array}$ & $\begin{array}{l}15-15-16 \\
\text { MIC }\end{array}$ & $\begin{array}{l}\text { 14- 15- } 14 \\
\text { Growth }\end{array}$ & $\begin{array}{l}\text { 12- 13- } 13 \\
\text { Growth }\end{array}$ & $\begin{array}{l}\text { 12- 13- } 13 \\
\text { Growth }\end{array}$ & $\begin{array}{l}\text { 9-9- } 10 \\
\text { Growth }\end{array}$ \\
\hline Savory & $\begin{array}{l}\text { Growth } \\
\text { MIC }\end{array}$ & $\begin{array}{l}\text { Growth } \\
\text { Growth }\end{array}$ & $\begin{array}{l}\text { Growth } \\
\text { Growth }\end{array}$ & $\begin{array}{l}\text { Growth } \\
\text { Growth }\end{array}$ & $\begin{array}{l}\text { Growth } \\
\text { Growth }\end{array}$ & $\begin{array}{l}\text { Growth } \\
\text { Growth }\end{array}$ & $\begin{array}{l}\text { Growth } \\
\text { Growth }\end{array}$ \\
\hline Lemon & $\begin{array}{l}\text { 15- 15-16 } \\
\text { MIC }\end{array}$ & $\begin{array}{l}\text { 14- 14- } 15 \\
\text { MIC }\end{array}$ & $\begin{array}{l}13-13-14 \\
\text { MIC }\end{array}$ & $\begin{array}{l}\text { 14- 13- } 14 \\
\text { Growth }\end{array}$ & $\begin{array}{l}\text { 8- 9- } 9 \\
\text { Growth }\end{array}$ & $\begin{array}{l}\text { 7- 8- } 8 \\
\text { Growth }\end{array}$ & $\begin{array}{l}\text { Growth } \\
\text { Growth }\end{array}$ \\
\hline
\end{tabular}


additives and preservatives or with natural and safe preservatives. In the meantime, in recent years, several studies have been conducted on the antibacterial and the antioxidant effects of plant seed extracts.

Ghasemi et al. (2009) showed that the essential oil of Thymus aenensis and other species of thyme (ecotype Elam) have antimicrobial activity against L. monocytogenes present in chicken. In this study, the minimum inhibition concentration for 50\% growth inhibition $<$ MIC against $L$. monocytogenes for Thymus daenensis and Thymus sp. Were 70.0 and $7.1 \mathrm{mg} / \mathrm{ml}$, respectively (Mahboubi and Kazempour 2011). According to the Rasouli and colleagues (2006), the extract and the essential oil of Thymus erioealyx and T. Porlock inhibits the growth of $L$. monocytogenes. The essential oils and the extracts of some aromatic plants (such as the mint family, Lamiaceae) with a high percentage of Carvacrol and thymol, have good activity against some bacteria (Chedea et al. 2013). Zdenka and colleagues (2004) showed the effect of antibacterial activity of the ethanol extract derived from the pulp and the seed of grapefruit against Staphylococcus aureus, Proteus vulgaris, Klebsiella pneumoniae, Candida albicans and other flora and the results showed that the extract of grapefruit seed has positive effects on the mortality of microorganisms (Cvetnic and Vladimir-Knezevic 2004). Joseph et al. (2009) showed that grape skin has the highest antimicrobial activity compared to the seeds (Brown et al. 2009). Veronica et al. (2011) showed in a study the effectiveness of phenolic extract against grampositive bacterium linens and reducing the growth of $E$. coli (Chedea et al. 2013).

Jalali et al. (1385), studied the antimicrobial effects of hydroalcoholic extract derived from eucalyptus, rosemary, thyme, chamomile and sage on $L$. monocytogenes and showed that only the eucalyptus has antibacterial effects against $L$. monocytogenes. In a study by Mena and his colleagues in Portugal (2004) on commercial food production, the contamination of L. monocytogenes was reported $7.17 \%$ in raw meat, $7.16 \%$ in raw milk, $6.12 \%$ in raw fish, 18.5\% in flour and 12.9\% in fresh vegetables (Mena et al. 2004). In this study, the Bakhtiari savory showed the greatest antimicrobial effect against $L$. monocytogenes with a high percentage of carvacrol. After the Savory Bakhtiari, the grape pulp with anthocyanins and flavonoids chemical compounds, and the lemon with limonene chemical compounds had the highest antimicrobial effect against $L$. monocytogenes, respectively. Their inhibitory effects were studied and approved by the MBC and MIC tests in vitro and in the minced meat.

\section{CONCLUSION}

The study showed that the Bakhtiari Savory extract and then the grape pulp had the best inhibitory effect on $L$. monocytogenes both in vitro and in food. On the other hand, it was shown that the Bakhtiari Savory could be effective as a preservative to increase meat durability and to prevent the growth of pathogens such as $L$. monocytogenes.

\section{ACKNOWLEDGEMENTS}

The authors would like to thanks from the Dr. Farhad Safarpoor Dehkordi in the Department of Food Hygiene of the University of Tehran for his technical support. This work was support by the Islamic Azad University of Shahrekord (Grant number: MSAB 220146).

\section{REFERENCES}

Brown, J. C., Huang, G., Haley-Zitlin, V. and Jiang, X. (2009): Antibacterial effects of grape extracts on Helicobacter pylori. Appl Environ Microbiol. 75, 848-852.

Camargo, A. C., de Castilho, N. P. A., da Silva, D. A. L., Vallim, D. C., Hofer, E. and Nero, L. A. (2015): Antibiotic Resistance of Listeria monocytogenes Isolated from Meat-Processing Environments, Beef Products, and Clinical Cases in Brazil. Microb Drug Resist. 21, 458-462.

Chedea, V. S., Braicu, C., Chirilă, F., Ober, C. and Socaciu, C. (2013): Antibacterial action of an aqueous grape seed polyphenolic extract. Afr J Biotechnol. 10, 6276-6280.

Cvetnic, Z. and Vladimir-Knezevic, S. (2004): Antimicrobial activity of grapefruit seed and pulp ethanolic extract. Acta Pharm. 54, 243-250.

Dehkordi, F. S., Barati, S., Momtaz, H., Ahari, S. N. H. and Dehkordi, S. N. (2013): Comparison of Shedding, and Antibiotic Resistance Properties of Listeria monocytogenes Isolated From Milk, Feces, Urine, and Vaginal Secretion of Bovine, Ovine, Caprine, Buffalo, and Camel Species in Iran. Jundishapur J Microbiol. 6, 284-94.

Di Pinto, A., Novello, L., Montemurro, F., Bonerba, E. and Tantillo, G. (2010): Occurrence of Listeria monocytogenes in ready-to-eat foods from supermarkets in Southern Italy. New Microbiol. 33, 249-252.

Goh, S., Kuan, C., Loo, Y., Chang, W., Lye, Y., Soopna, P., Tang, J., Nakaguchi, Y., Nishibuchi, M. and Afsah-Hejri, L. (2012): Listeria monocytogenes in retailed raw chicken meat in Malaysia. Poultry Sci. 91; 2686-2690.

Granier, S. A., Moubareck, C., Colaneri, C., Lemire, A., Roussel, S., Dao, T.-T., Courvalin, P. and Brisabois, A. (2011): Antimicrobial resistance of Listeria monocytogenes isolates from food and the environment in France over a 10-year period. Appl Environ Microbiol. 77, 2788-2790.

Gray, M. J., Zadoks, R. N., Fortes, E. D., Dogan, B., Cai, S., Chen, Y., Scott, V. N., Gombas, D. E., Boor, K. J. and Wiedmann, M. (2004): Listeria monocytogenes isolates from foods and humans form distinct but overlapping populations. Appl Environ Microbiol. 70, 5833-5841. 
Indrawattana, N., Nibaddhasobon, T., Sookrung, N., Chongsanguan, M., Tungtrongchitr, A., Makino, S.-i., Tungyong, W. and Chaicumpa, W. (2011): Prevalence of Listeria monocytogenes in raw meats marketed in Bangkok and characterization of the isolates by phenotypic and molecular methods. J Health Population Med. 29, 26-38.

Kang, C.-G., Hah, D.-S., Kim, C.-H., Kim, Y.-H., Kim, E. and Kim, J.-S. (2011): Evaluation of antimicrobial activity of the methanol extracts from 8 traditional medicinal plants. Toxicol Res. 27, 31.

Mahboubi, M. and Kazempour, N. (2011): Chemical composition and antimicrobial activity of Satureja hortensis and Trachyspermum copticum essential oil. Iranian J Microbiol. 3, 194-200.

Mataragas, M., Drosinos, E., Siana, P., Skandamis, P. and Metaxopoulos, I. (2006): Determination of the growth limits and kinetic behavior of Listeria monocytogenes in a sliced cooked cured meat product: validation of the predictive growth model under constant and dynamic temperature storage conditions. J Food Protect. 69, 1312-1321.

Mena, C., Almeida, G., Teixeira, P., Hogg, T. and Gibbs, P. A. (2004): Incidence of Listeria monocytogenes in different food products commercialized in Portugal. Food Microbiol. 21, 213-216.
Morvan, A., Moubareck, C., Leclercq, A., Herve-Bazin, M., Bremont, S., Lecuit, M., Courvalin, P. and Le Monnier, A. (2010): Antimicrobial resistance of Listeria monocytogenes strains isolated from humans in France. Antimicrob Agent Chemother. 54, 2728-2731.

Oliveira, D. A., Salvador, A. A., Smânia, A., Smânia, E. F., Maraschin, M. and Ferreira, S. R. (2013): Antimicrobial activity and composition profile of grape (Vitis vinifera) pomace extracts obtained by supercritical fluids. J Biotech. 164, 423432.

Reddy, S. and Lawrence, M. L. (2014): Virulence Characterization of Listeria monocytogenes. Listeria monocytogenes. Methods Mol Biol. 1157, 157-165.

Siriken, B., Ayaz, N. D. and Erol, I. (2013): Listeria monocytogenes in retailed raw chicken meat in Turkey. Berliner und Munchener tierarztliche Wochenschrift. 127, 43-49.

Tompkin, R. (2002): Control of Listeria monocytogenes in the food-processing environment. J Food Protect. 65, 709725.

Zhang, L., Moosekian, S. R., Todd, E. C. and Ryser, E. T. (2012): Growth of Listeria monocytogenes in different retail delicatessen meats during simulated home storage. J Food Protect. 75, 896-905. 